\title{
PENGARUH RELAKSASI OTOT PROGRESIF TERHADAP PENURUNAN KADAR GULA DARAH PADA PASIEN DIABETES MELITUS DI WILAYAH PUSKESMAS WOHA - BIMA TAHUN 2018
}

\author{
Ns. Junaidin \\ STIKES Yahya Bima \\ junaidinstikesyahya@gmail.com
}

\begin{abstract}
Abstrak; Meningkatnya jumlah penderita Diabetes Melitus (DM) dapat disebabkan oleh banyak faktor, diantaranya adalah faktor keturunan/genetik, obesitas, perubahan gaya hidup, pola makan yang salah, obat-obatan yang mempengaruhi kadar glukosa darah, kurangnya aktifitas fisik, proses menua, kehamilan, perokok dan stress. Penanganan Diabetes Melitus (DM) di rumah sakit yang ada selama ini masih sebagian besar berfokus pada pengobatan konvensional yang telah diprogramkan oleh dokter, belum memperhatikan penanganan stress pasien, sedangkan faktor psikologis sangat berpengaruh terhadap kondisi kesehatan pasien. Harapannya setelah pemberian teknik relaksasi otot progresif dapat menrunkan kadar gula darah pasien diabetes melitus. Tujuan penelitian ini adalah untuk membandingkan kadar gula darah antara pengobatan dengan tidak didampingi intervensi relaksasi otot progresif dan pengobatan dengan didampingi intervensi teknik relaksasi otot progresif pada orang yang sama. Jenis penelitian ini adalah kuasi eksperimen dengan pre and post control group, yaitu suatu desain yang memberikan perlakuan pada dua atau lebih kelompok, kemudian diobservasi sebelum dan sesudah implementasi. Desain ini digunakan untuk membandingkan hasil intervensi dua kelompok, yaitu kelompok intervensi dan kelompok kontrol yang keduanya diukur sebelum dan sedah melakukan intervensi. Teknik pengambilan sampel dilakukan dengan cara consecutive sampling, yaitu merekrut semua subjek yang memenuhi kriteria inklusi dalam waktu tertentu. Berdasarkan hasil yang diperoleh dalam penelitian ini, terlihat bahwa latihan relaksasi otot progresif mempunyai pengaruh yang signifikan terhadap penurunan kadar glukosa darah pada pasien diabetes melitus (DM). Peneliti meyakini bahwa relaksasi otot progresif memberikan pengaruh yang signifikan dalam menurunkan KGD pasien diabetes melitus (DM) dalam penelitian ini dengan beberapa alasan, diantaranya penelitian ini menggunakan desain kuasi eksperiman dengan pre and post with control group, variabel karakteristik responden setara (homogen) antara kelompok intervensi dengan kelompok kontrol, dan variabel rata-rata kadar glukosa darah sebelum intervensi setara antara kelompok intervensi dan kelompok kontrol.
\end{abstract}

\section{Kata kunci: relaksasi otot progresif, gula darah.}

\section{PENDAHULUAN}

Proses menua merupakan proses yang berlanjut secara alamiah, dimulai sejak lahir dan pada umumnya dialami pada semua makhluk hidup (Nugroho, 2008). Penyakit degeneratif pada lansia yang disebabkan oleh penurunan fungsi adalah Diabetes Mellitus dan Hipertensi (Subroto, 2006). Penyakit tersebut akan dapat mengganggu aktifitas lansia dalam memenuhi kebutuhan sehari-hari (Sutikno, 2011). Indonesia termasuk 10 besar negara dengan jumlah penderita Diabetes Melitus (DM) terbanyak. Pada tahun 2000 jumlahnya 8.426.000 orang, dan WHO memprediksi pada tahun 2030 jumlah ini akan meningkat menjadi 21.257.000 orang (WHO, 2012).

Diabetes Melitus (DM) merupakan salah satu penyakit degeneratif, yaitu penyakit akibat fungsi atau struktur dari jaringan atau organ tubuh yang secara progresif menurun dari waktu ke waktu karena usia atau gaya hidup. Diabetes Mellitus sifatnya bukan bawaan dari lahir tetapi disebabkan oleh factor gaya hidup dan makanan yang dikonsumsi setiap hari serta faktor degenaratif, sehingga pada umumnya penderita Diabetes Mellitus adalah mereka yang berumur lebih dari 30 tahun. Selain itu, 
Diabetes Mellitus sering tidak didiagnosis sampai komplikasi muncul (Foreman , 2011).

Diabetes Melitus (DM) merupakan penyakit gangguan metabolisme menahun/kronik yang ditandai dengan peningkatan kadar glukosa darah (hiperglikemi) yang disebabkan karena jumlah insulin yang kurang atau jumlah insulin cukup bahkan kadang-kadang lebih akan tetapi kurang efektif, kondisi ini disebut dengan resistensi insulin (Waspadji, 2012). Berbagai penelitian epidemiologi menunjukkan adanya kecenderungan peningkatan angka insidensi dan prevalensi Diabetes Melitus (DM) di berbagai penjuru dunia termasuk juga di Indonesia (Perkeni, 2011).

Meningkatnya jumlah penderita Diabetes Melitus (DM) dapat disebabkan oleh banyak faktor, diantaranya adalah faktor keturunan/genetik, obesitas, perubahan gaya hidup, pola makan yang salah, obat-obatan yang mempengaruhi kadar glukosa darah, kurangnya aktifitas fisik, proses menua, kehamilan, perokok dan stres (Soegondo, dkk , 2011). Pada penderita Diabetes Melitus (DM), stres fisiologi dan emosional seperti keadaan sakit, infeksi dan pembedahan dapat menimbulkan hiperglikemia. Sebagai respon terhadap stres akan terjadi peningkatan hormon-hormon stres yaitu glukagon, epinefrin, norepinefrin, kortisol dan hormon pertumbuhan. Hormon-hormon ini akan meningkatkan produksi glukosa oleh hati dan mengganggu penggunaan glukosa dalam jaringan otot serta lemak dengan cara melawan kerja insulin. Oleh karena itu diperlukan manajemen keperawatan yang tepat untuk mengatasi stres pada pasien selain terapi medis sehingga glukosa darah pasien dapat terkontrol, salah satunya adalah dengan terapi komplementer. Terapi komplementer yang sering digunakan pada pasien diabetes untuk membantu menurunkan kadar glukosa darah adalah Mind Body Medicine (Lorentz, 2006).

Penanganan Diabetes Melitus (DM) di rumah sakit yang ada selama ini masih sebagian besar berfokus pada pengobatan konvensional yang telah diprogramkan oleh dokter, belum memperhatikan penanganan stress pasien, sedangkan faktor psikologis sangat berpengaruh terhadap kondisi kesehatan pasien. Apabila stres yang dialami penderita diabetes dibiarkan saja, dengan kadar gula darah tetap tinggi dan tidak dikelola dengan baik, ditakutkan komplikasi akut (ketoasidosis diabetes/KAD, asidosis laktat, koma hiperosmolar hiperglikemik non ketotik) sampai komplikasi kronik (retinopati, nefropati, jantung koroner) dapat terjadi (Sudoyo, dkk, 2006). Sehingga dengan itu perlu penanganan secara holistik pada pasien Diabetes Melitus (DM).

Banyak cara yang dapat digunakan dalam penanganan stres diantaranya teknik relaksasi nafas dalam, teknik relaksasi otot progresif, terapi musik, terapi respon emosirasional, yoga, dan pendekatan agamis (Wade \& Tavns, 2007). Berbagai teknik tersebut merupakan suatu upaya meredakan ketegangan emosional sehingga individu dapat berpikir lebih rasional. Dengan demikian produksi gula hati dapat terkontrol dengan baik, dengan begitu gula darah dapat stabil normal. Salah satu bentuk cara meredakan ketegangan emosional yang cukup mudah dilakukan adalah relaksasi otot progresif (Suyamto, dkk, 2009). Teknik ini memaksa individu untuk berkonsentrasi pada ketegangan ototnya dan kemudian melatihnya untuk relaks. Orang yang stres, secara emosional tegang dan mengalami ketegangan otot. Teknik ini berusaha meredakan ketegangan otot dengan harapan bahwa ketegangan emosionalpun berkurang, maka dari itu teknik relaksasi otot progresif ini dapat digunakan untuk mendampingi teknik konvensional yang biasa diberikan.

Berdasarkan studi pendahuluan yang dilakukan oleh peneliti pada hari Rabu tanggal 17 Mei 2018 di PUSKESMAS Woha - Bima, Puskesmas ini belum menggunakan teknik nonfarmakologi dalam menangani pasien Diabetes Melitus (DM) tipe 2 pada pasien rawat inapnya, hanya menggunakan teknik konvensional tanpa ada intervensi nonfarmakologi. Berdasarkan studi pendahuluan yang dilakukan oleh peneliti pada hari Juma'at tanggal 26 Mei 2018, obat 
yang digunakan di Puskesmas tersebut menggunakan 2 jenis, yaitu dengan insulin dan obat oral. Pengobatan pada pasien rawat inap dengan insulin kurang lebih $75 \%$, namun dosis untuk setiap pasien berbeda-beda tergantung derajat keparahan atau tingginya gula darah pada pasien, sedangkan pengobatan pasien rawat inap dengan obat oral sekitar 25\%, dosis sudah dari pabrik. Dilihat dari jumlah pasien Diabetes Melitus (DM) dari tahun ke tahun di Puskesmas ini yang meningkat, yaitu pada tahun 2015 sebanyak 11 oarng, tahun 2016 sebanyak 13 orang dan tahun 2017 sebanyak 17 orang, intervensi nonfarmakologi teknik relaksasi otot progresif perlu dipertimbangkan. Teknik relaksasi otot progresif adalah teknik relaksasi otot dalam yang tidak memerlukan imajinasi, ketekunan, atau sugesti. Berdasarkan keyakinan bahwa tubuh manusia berespons pada kecemasan dan kejadian yang merangsang pikiran dengan ketegangan otot. Teknik relaksasi otot progresif memusatkan perhatian pada suatu aktivitas otot dengan mengidentifikasi otot yang tegang kemudian menurunkan ketegangan dengan melakukan teknik relaksasi untuk mendapatkan perasaan relaks (Herodes, 2010). Selain mudah dan praktis dilakukan, relaksasi otot progresif dapat digunakan untuk terapi sehari-hari yang digunakan penderita Diabetes Melitus (DM). Kita ketahui pula bahwa penyakit Diabetes Melitus (DM) merupakan penyakit kronis yang tidak dapat disembuhkan, sehingga perlu penanganan yang terus menerus untuk mengontrol hiperglikemi.

Berdasarkan uaraian di atas, maka peneliti tertarik untuk mengadakan penelitian tentang pengaruh relaksasi otot progresif terhadap penurunan kadar gula darah pada pasien diabetes mellitus di Puskesmas Woha - Bima tahun 2018.

\section{METODE PENELITIAN}

Jenis penelitian ini adalah kuasi eksperimen dengan pre and post control group, yaitu suatu desain yang memberikan perlakuan pada dua atau lebih kelompok, kemudian diobservasi sebelum dan sesudah implementasi (Polit and Beck, 2006). Desain ini digunakan untuk membandingkan hasil

Jurnal Ilmiah Mandala Education intervensi dua kelompok, yaitu kelompok intervensi dan kelompok kontrol yang keduanya diukur sebelum dan sedah melakukan intervensi (Notoatmojo, 2005). Kelompok kontrol dalam penelitian ini penting untuk melihat perbedaan perubahan variabel terikat antara kelompok intervensi dan kelompok control.

\section{HASIL DAN PEMBAHASAN \\ 1 Karakteristik demografi responden.}

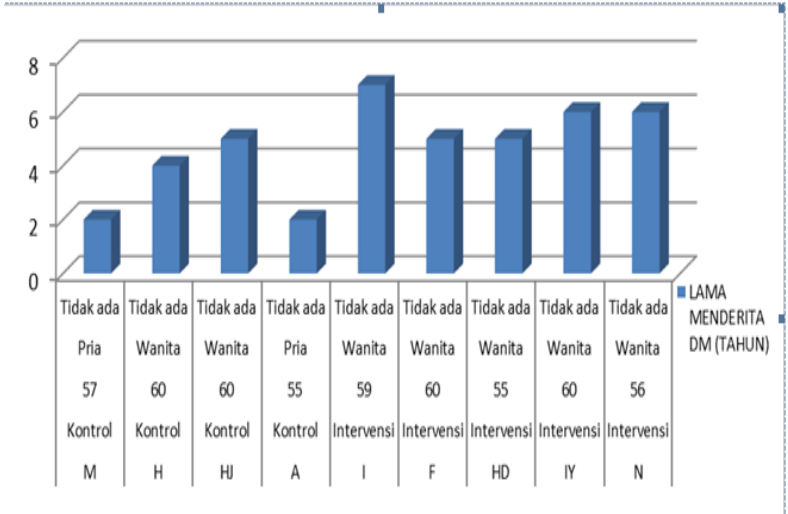

Distribusi responden berdasarkan umur.

Berdasarkan diagram di atas, usia responden yang berusia 55 tahun sebanyak 2 orang, yang berusia 56 tahun 1 orang, yang berusia 57 tahun 1 orang, yang berusia 59 tahun 1 orang dan yang berusia 60 tahun sebanyak 4 orang.

\section{Distribusi responden berdasarkan jenis kelamin}

Berdasarkan diagram diatas, responden yang berjenis kelamin perempuan atau wanita lebih sebanyak 7 orang sedangkan responden yang berjenis kelakin laki-laki atau pria adalah sebanyak 2 orang.

\section{Distribusi responden berdasarkan penyakit penyerta}

Berdasarkan diagram diatas, bahwa semua responden tidak mempunyai penyakit penyerta.

\section{Variabel Yang Diukur}

1. Kadar gula darah sebelum dan sesudah intervensi

Tabel 5.1 Kadar gula darah responden sebelum dan sesudah intervensi 


\begin{tabular}{|c|c|c|c|}
\hline \multirow{2}{*}{ No } & \multirow{2}{*}{ Responden } & \multicolumn{2}{|c|}{ Kadar Gula Darah } \\
\cline { 3 - 4 } & & Sebelum Intervensi & Sesudah Intervensi \\
\hline 1 & M & 240 & 221 \\
\hline 2 & H & 260 & 243 \\
\hline 3 & HJ & 225 & 207 \\
\hline 4 & A & 255 & 240 \\
\hline 5 & I & 245 & 179 \\
\hline 6 & F & 237 & 165 \\
\hline 7 & HD & 230 & 159 \\
\hline 8 & IY & 255 & 187 \\
\hline 9 & N & 247 & 177 \\
\hline
\end{tabular}

Berdasarkan tabel di atas, tampak bahwa kadar gula darah tertinggi sebelum intervensi adalah 260 dan kadar gula terendah adalah 225, sedangkan kadar gula tertinggi sesudah intervensi adalah 240 dan kadar gula terendah adalah 159 .

2. Hasil Analisis Kadar Gula Darah

Tabel 5.2 Hasil Analisis kadar gula darah

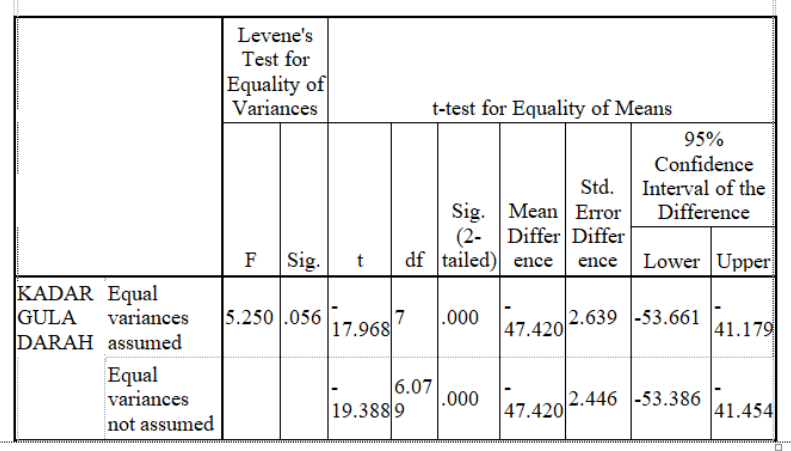

Berdasarkan tabel diatas bahwa ada signifikan kadar gula darah sebelum intervensi dan sesudah intervensi sebesar 0,056 pada tingkat kepercayaan $95 \%$.

Setelah dilakukan analisis dan melihat hasilnya, maka ada beberapa hal yang akan dibahas yaitu : kadar gula darah sebelum intervensi, kadar gula darah sesudah intervensi dan pengaruh relaksasi otot progresif terhadap penurunan kadar gula darah

Kadar gula darah kelompok kontrol sebelum dan sesudah intervensi

Data hasil penelitian yang telah dilaksanakan di lingkungan Puskesmas Woha, bahwa semua responden sebelum masuk Puskesmas memiliki kadar gula darah di atas $200 \mathrm{mg} / \mathrm{dL}$.

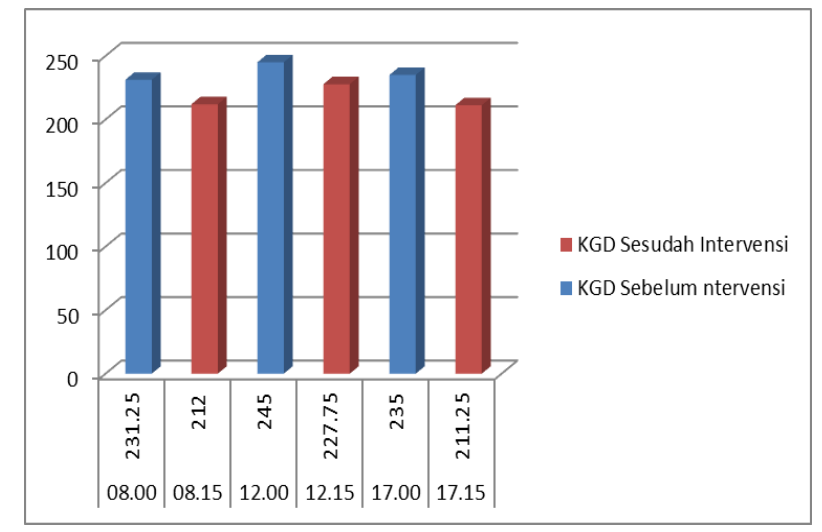

Diagram Rata-rata KGD kelompok kontrol sebelum intervensi dan sesudah intervensi.

Dari diagram diatas, bahwa rata-rata kadar gula darah kelompok kontrol jam 08.00 sebelum intervensi sebesar $231,25 \mathrm{mg} / \mathrm{dL}$ sedangkan rata-rata kadar gula darah jam 08.00 sesudah intervensi sebasar $212 \mathrm{mg} / \mathrm{dL}$. Sementara rata-rata kadar gula darah kelompok kontrol jam 12.00 sebelum intervensi sebesar $245 \mathrm{mg} / \mathrm{dL}$, sedangkan rata-rata kadar gula darah kelompok kontrol jam 12.00 sesudah intervensi sebesar 227,75 $\mathrm{mg} / \mathrm{dL}$. Dan rata-rata kadar gula darah kelompok kontrol jam 17.00 sebelum intervensi sebesar $235 \mathrm{mg} / \mathrm{dL}$, sedangkan rata-rata kadar gula darah kelompok kontrol jam 17.00 sesudah intervensi adalah sebesar $211,25 \mathrm{mg} / \mathrm{dL}$.

Kadar gula darah kelompok intervensi sebelum dan sesudah intervensi

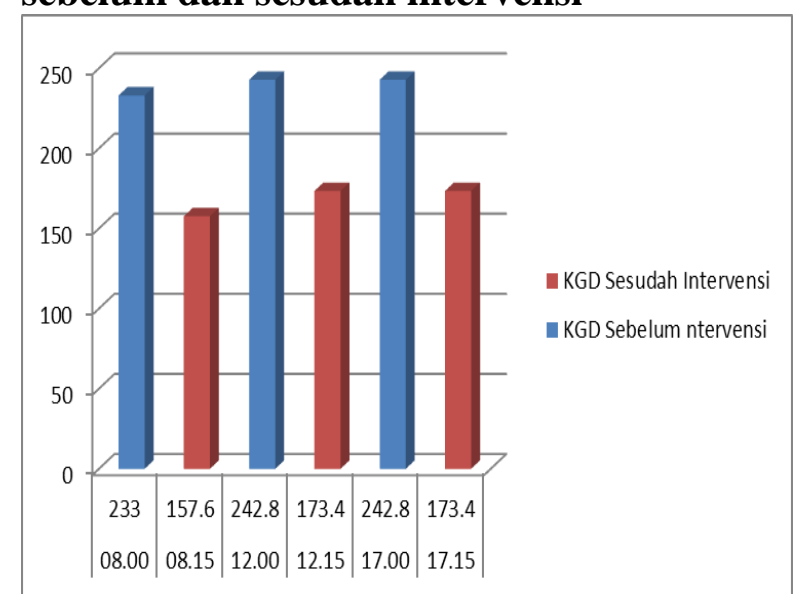

Diagram Rata-rata kadar gula darah kelompok intervensi sebelum dan sesudah intervensi.

Dari diagram diatas diperoleh bahwa rata-rata kadar gula darah kelompok intervensi jam 08.00 sebelum intervensi 
sebesar $233 \mathrm{mg} / \mathrm{dL}$, sedangkan rata-rata kadar gula darah kelompok intervensi jam 08.00 sesudah intervensi sebesar 157,6 mg/dL. Sementara rata-rata kadar gula darah kelompok intervensi jam 12.00 sebelum intervensi sebesar $242,8 \mathrm{mg} / \mathrm{dL}$, sedangkan rata-rata kadar gula darah kelompok intervensi jam 12.00 sesudah intervensi sebesar 173,4 mg/dL. Dan rata-rata kadar gula darah kelompok intervensi jam 17.00 sebelum intervensi sebesar $233 \mathrm{mg} / \mathrm{dL}$, sedangkan rata-rata kadar gula darah kelompok intervensi jam 17.00 sesudah intervensi sebesar 157,6 mg/dL.

\subsection{Pengaruh Relaksasi otot progresif terhadap penurunan kadar gula darah}

Relaksasi otot progresif merupakan salah satu teknik relaksasi yang mudah dan sederhana serta sudah digunakan secara luas. Relaksasi otot progresif merupakan suatu prosedur untuk mendapatkan relaksasi pada otot melalui dua langkah, yaitu dengan memberikan tegangan pada suatu kelompok otot, dan menghentikan tegangan tersebut kemudian memusatkan perhatian terhadap bagaimana otot tersebut menjadi rileks, merasakan sensasi rileks, dan ketegangan menghilang (Richmond, 2007).

Relaksasi merupakan salah satu bentuk mind-body therapy dalam terapi komplementer dan alternatif (Complementary and Alternative Therapy /CAM) (Moyad \& Hawks, 2009). Terapi komplementer adalah pengobatan tradisional yang sudah diakui dan dapat dipakai sebagai pendamping terapi konvensional medis. Pelaksanaannya dapat dilakukan bersamaan dengan terapi medis (Moyad \& Hawks, 2009).

Relaksasi otot progresif merupakan salah satu intervensi keperawatan yang dapat diberikan kepada pasien diabetes mellitus (DM) untuk meningkatkan relaksasi dan kemampuan pengelolaan diri. Latihan ini dapat membantu mengurangi ketegangan otot, stres, menurunkan tekanan darah, meningkatkan toleransi terhadap aktivitas sehari-hari, meningkatkan imunitas, sehingga status fungsional dan kualitas hidup meningkat (Smeltzer \& Bare, 2002).

Jurnal Ilmiah Mandala Education
Hasil penelitian ini menunjukkan bahwa pasien diabetes melitus (DM) yang diberi latihan Relaksasi otot progresif selama tiga hari dengan frekuensi latihan dua kali sehari dan durasi masing-masing sesi \pm 15 menit memperlihatkan adanya perbedaan ratarata KGD baik KGD jam 08.00, 12.00, dan 17.00 sebelum dan setelah latihan Relaksasi otot progresif, yaitu mengalami penurunan kadar glukosa darah.

Berdasarkan hasil yang diperoleh dalam penelitian ini, terlihat bahwa latihan relaksasi otot progresif mempunyai pengaruh yang signifikan terhadap penurunan kadar glukosa darah pada pasien diabetes melitus (DM). Peneliti meyakini bahwa relaksasi otot progresif memberikan pengaruh yang signifikan dalam menurunkan KGD pasien diabetes melitus (DM) dalam penelitian ini dengan beberapa alasan, diantaranya penelitian ini menggunakan desain kuasi eksperiman dengan pre and post with control group, variabel karakteristik responden setara (homogen) antara kelompok intervensi dengan kelompok kontrol, dan variabel ratarata kadar glukosa darah sebelum intervensi setara antara kelompok intervensi dan kelompok kontrol.

Mekanisme relaksasi otot progresif dalam menurunkan KGD pada pasien diabetes melitus (DM) erat kaitannya dengan stres yang dialami pasien baik fisik maupun psikologis. Selama stres, hormon-hormon yang mengarah pada peningkatan KGD seperti epineprin, kortisol, glukagon, ACTH, kortikosteroid, dan tiroid akan meningkat. Selain itu peristiwa kehidupan yang penuh stres telah dikaitkan dengan perawatan diri yang buruk pada penderita diabetes seperti pola makan, latihan, dan penggunaan obatobatan (Smeltzer \& Bare, 2008; Price \& Wilson, 2006). Stres fisik maupun emosional mengaktifkan sistem neuroendokrin dan sistem saraf simpatis melalui hipotalamuspituitari-adrenal (Price \& Wilson, 2006; Smeltzer, 2002; DiNardo, 2009).

Relaksasi otot progresif merupakan salah satu bentuk mind-body therapy (terapi pikiran dan otot-otot tubuh) dalam terapi komplementer (Moyad \& Hawks, 2009). 
Brown 1997 dalam Snyder \& Lindquist (2002) menyebutkan bahwa respon stres merupakan bagian dari jalur umpan balik yang tertutup antara otot-otot dan pikiran. Penilaian terhadap stressor mengakibatkan ketegangan otot yang mengirimkan stimulus ke otak dan membuat jalur umpan balik. relaksasi otot progresif akan menghambat jalur tersebut dengan cara mengaktivasi kerja sistem saraf parasimpatis dan memanipulasi hipotalamus melalui pemusatan pikiran untuk memperkuat sikap positif sehingga rangsangan stres terhadap hipotalamus berkurang.

Tampak pada penelitian ini dengan perlakuan yang sama yaitu terapi relaksasi otot progresif ternyata rentang penurunan KGD jam 08.00, 12.00, dan 17.00 setiap responden berbeda-beda. Responden dalam penelitian ini melaporkan bahwa pada saat melakukan relaksasi otot progresif ada dua sensasi yang berbeda yaitu merasakan ketegangan otot ketika bagian otot-otot tubuhnya diteganggkan dan merasakan sesuatu yang rileks, nyaman, enak, dan santai ketika otot-otot tubuh yang sebelumnya ditegangkan tersebut direlaksasikan. Namun ada beberapa responden yang melaporkan kurang bisa merasakan sensasi dari latihan relaksasi otot progresif yang dilakukannya karena mereka kurang bisa berkonsentrasi dalam melakukan relaksasi otot progresif tersebut, meskipun dirinya bisa melakukan semua langkah atau prosedur relaksasi otot progresif. Hal ini sesuai dengan pernyataan Richmond (2007), bahwa relaksasi otot progresif merupakan salah satu bentuk mindbody therapi, oleh karena itu saat melakukan relaksasi otot progresif perhatian diarahkan untuk membedakan perasaan yang dialami saat kelompok otot dilemaskan dan dibandingkan ketika otot-otot dalam kondisi tegang.

Penelitian ini sejalan dengan pernyataan Dunning (2003) bahwa terapi komplementer memberikan manfaat pada pasien diabetes melitus (DM) diantaranya meningkatkan penerimaan kondisi diabetes mellitus (DM) saat ini, menurunkan stres, kecemasan, dan depresi, mengembangkan strategi untuk mencegah stres berkelanjutan, meningkatkan keterlibatan pasien dalam proses penyembuhan. Keuntungan terapi komplementer secara spesifik bagi pasien diabetes juga dikemukakan oleh Riyadi \& Sukarmin (2008) yaitu menurunkan KGD, meningkatkan kontrol metabolik, mencegah neuropati perifer, menurunkan kadar katekolamin dan aktivitas otonom.

\section{KESIMPULAN}

Berdasarkan hasil penelitian ini dapat disimpulkan bahwa terdapat pengaruh relaksasi otot progresif terhadap penurunan gula darah pada pasien diabetes mellitus (DM) di lingkungan Puskesmas Woha tahun 2018.

\section{SARAN}

Bagi Pelayanan Keperawatan, latihan relaksasi otot progresif dapat dijadikan salah satu intervensi keperawatan mandiri untuk membantu menurunkan kadar glukosa darah pasien diabetes melitus (DM). Berdasarkan hasil penelitian ini, diharapkan perawat dapat meningkatkan pengetahuan dan keterampilan melalui seminar atau pelatihan terkait teknik relaksasi otot progresif dan melakukan evidence based practice.

\section{DAFTAR PUSTAKA}

Andra, S. (2013). KMB 1 Keperawatan Medikal Bedah Keperawatan Dewasa Teori dan Contoh Askep. Yogyakarta: Nuha Medika.

Black, M.J. 1998. Medical surgical nursing: clinical management for contivity of care. Tokyo: WB Saunder Company.

Chaplin, J. P. 2005. Kamuslengkappsikologi. Alih bahasa: Dr. KartiniKartono. Jakarta: Raja GrafindoPersada.

Charlesworth dan Nathan, 1996. Stress management: a comprehensive guide to wellness. Souvenir Press Ltd.

Corwin. 2009, Buku saku patofisiologi, 3 edn, EGC, Jakarta.

Dahlan S. 2008. Statistik Untuk Kedokteran dan Kesehatan. Jakarta: Salemba Medika.

Dierendonck, D.V.,danJan, T.N. 2005. Flotation restricted environmental stimulation therapy (REST) as a stress- 
management tool: A Meta-Analysis. Psychology and Health,

Foreman 2011. Cancer's toll on marriage. Loa angeles time

Greenberg, J. S. 2002. Comprehensive: stress management. Edisi ketujuh. New York: America.

Herodes. 2010. Teknik relaksasi progresif terhadap insomnia lansia.

Hewitt, P. L., danDyck, D. G. 1986. Perfectionism, stress, and vulnerability to depression.Cognitive Therapy and Research

Jones, R. N. 1996. Teori dan Praktik Konseling dan Terapi. Yogyakarta: Pustaka Pelajar.

Lorentz. 2006. Stress and psychoneuroimmulogy revisited : Using Mind Body Intervention to reduse Stress. Alternative journal of Nursing.

Mansjoer, A. dkk. 2005. Kapita Selekta Kedokteran Edisi ketiga Jilid 1 Cetakan keenam. Jakarta: Media Aesculapius Fakultas Kedokteran UI

Moyad, M. d. (2009). Complementary and alternative therapies, dalam Black, J.M., \& Hawks, J.H. Medical-Surgical Nursing; Clinical Managemen for Positive Outcomes, (8 th edition). Elsevier Saunders.

Murphy, J. 1996. The power of your subconscious mind. Alih bahasa. Jakarta: Spektrum.

Notoatmodjo S. 2005. Metodologi Penelitian Kesehatan. Jakarta: Rineka Cipta

Nugroho. 2008. Perawatan usia lanjut. Jakarta : EGC

Perkeni. 2011. Panduan penatalaksanaan penyakit diabetes mellitus. Jakarta : perkeni

Polit, D. F., \& Beck, C.T. (2006). The content validity index: Are you know whats being reported?. Research in Nursing \& Health, 29, 489-497.

Price, dkk. 2006. Konsep klinis proses-proses penyakit. Edisi ketiga. Jakarta : erlangga

Purnamasari, 2009. Diagnosis dan Klasifikasi Diabetes Melitus. In: Sudoyo, A.W.,

Jurnal Ilmiah Mandala Education
Richmond, R.L. (2007). A Guide to Psychology and its Practice. Diunduh dari

http://www.guidetopsychology.com/pmr.htm tanggal 28 Agustus 2017.

Ryadi, A. (2003). Diabetes (1 ed). Jakarta: PT Dian Rakyat.

Salim, P. 1991. Kamus besar bahasa indonesia. Jakarta: Balai Pustaka.

Setiyohadi, B., Alwi, I., Simadibrata, M., Setiati, S., Buku Ajar Ilmu Penyakit Dalam Jilid III Edisi V. Jakarta: Interna Publishing Pusat Penerbitan Ilmu Penyakit Dalam

Smeltzer, S.C., \& Bare, B.G. (2008). Brunner \& Suddarth's: Texbook of medical

surgical nursing. Philadelphia: Lippincott

Soegondo, dkk. 2011. Penatalaksanaan diabetes terpadu. Jakarta : balai penerbit FKUI

Soewondo, S. 2012. Stres,manajemen stres, dan relaksasi progresif. Depok: LPSP3 UI

Subandi, M.A. 2002. Psikoterapi pendekatan konvensional dan kontempor. Yogyakarta: Unit Publikasi Fakultas Psikologi UGM dan Pustaka Pelajar.

Subroto. 2006. Penatalaksanaan diabetes. http://google.com. Di akses tanggal 12 juni 2017.

Sudoyo, dkk. 2006. Buku Ajar Ilmu penyakit Dalam. Edisi 4, Jilid 1. Jakarta : Departemen Ilmu Penyakit Dalam FKUI.

Sutikno. 2011. Hubungan antara fungsi keluarga dan kualitas hidup lansi. Med J Indonesia; 2011

Suyamto, dkk. (2009). Pengaruh Relaksasi Otot dalam Menurunkan Skor Kecemasan T-TMAS Mahasiswa Menjelang Ujian Akhir Program Di Akademi Keperawatan Notokusumo Yogyakarta. Berita Kedokteran Masyarakat

Townsend, M.C. 1999. Psychiatric mental health nursing. Third Edition. Philadelphia: F.A Davis Company.

Utami, M.S. 1991. Efektivitas relaksasi dan terapi kognitif untuk mengurangi kecemasan berbicara di muka 
JIME, Vol. 4. No. 1

umum.Tesis (tidak diterbitkan). Yogyakarta: Fakultas Psikologi UGM

Waspadji. 2011. Buku ajar penyakit dalam : komplikasi kronik diabetes, mekanisme terjadinya, diagnosis dan strategi pengelolaan. Jakarta : FKUI

Zaenal, A. 2009. BAB II TINJAUAN PUSTAKA - Perpustakaan Universitas Indonesia.

http://freedownloadsff.com/pengaruhteknik-relaksasi-autogenik pengaruh teknik relaksasi autogenik.pdf. Diakses 13 Juni 2017. 